\title{
A Welfare Based Approach for choosing the Inflation Targeting and the Exchange Regime in Tunisia
}

\author{
${ }^{*}$ Abdelli Soulaima1, Belhadj Besma² \\ ${ }^{1}$ LAREQUAD, University el Manar, Tunis, Tunisia \\ ${ }^{2}$ LAREQUAD, University of Carthage, Tunis, Tunisia \\ *selima11@yahoo.fr
}

\begin{abstract}
The inflation targeting is considered as an attractive monetary policy strategy in order to handle the inflation rate and improves the credibility of the central bank. The paper provides a stochastic dynamic general equilibrium model with the specificity of employing a small open economy. This model analyzes the impact of different regimes of inflation targeting and exchange rate in Tunisia in terms of the welfare loss and describes some aspects of the Tunisian's economy. The results displays that the social loss is higher under the managed exchange rate than the flexible exchange rate regime for all the shocks. Then in terms of the inflation targeting index, it demonstrates that the consumer prices index outperforms the domestic inflation except for the productivity shock, in contrast to the result of (Parrado, 2004). Finally the strict is superior to the flexible inflation targeting except with the foreign inflation and the domestic interest rate shock.
\end{abstract}

Keywords: Welfare analysis, inflation targeting, open economy, exchange rates

\section{Introduction}

For a long time, the choice of an appropriate inflation targeting (IT) and between targeting managed or floating exchange rate has been a focus of many researches. This is explained by the liberalization of the international financial transactions and the huge increase of their volume that is followed. How would the features of the economy affect this choice? What are the different implications in terms of the macroeconomic performance or the welfare? Many empirical studies suggest that when pursuing the (IT), the developing countries should not neglect the exchange rate target to avoid the high exchange rate volatility and the impact on the firm's profitability. A few theoretical and empirical studies that have treated this kind of regime for the small open economies. The problem is treated in this case for the lack of interest as confirmed by Parrado (2004). In addition according to Peiris \& Saxegaard (2007) there is not lot of papers that have attacked the subject of the trade-offs between monetary policies rules in the Sub-Saharan Africa (SSA) and the low-income countries. The model is different from many recent papers in many points. First it emphasized on a small open economy while most of the other studies concentrated on a world economy composed of two countries excepting Gali \& Monacelli (2002). Second we note the difficulty of some central banks to support the exchange rate system, strengthen the anchor problem: the exchange rate or the inflation target Parrado (2004). Third, it has been shown that the trade between the countries and the mobility of the capital markets as well as the remittance inflow encourage the researcher to find out how to adapt the monetary and the exchange rate policies to this new regime and to distinguish which kind of regime is more adaptable for the small open economy in terms of stability, especially in Tunisia. Remittances are considered as a foreign consumption shock that has impact on the domestic economy by incorporating a negative preference shock parameter in the foreign household utility function. This latter will invest or remit income in the domestic economy at the detriment of his own consumption.

It is reported that the profit remittance on the Foreign Direct Investment (FDI) in Tunisia recognized an ascending trend since 1980. To stabilize the real economy and to show the interest of modeling the dynamic stochastic general equilibrium (DSGE), some authors focused on the tradeoffs between the monetary policy rules. For example Peiris \& Saxegaard (2007) studied the monetary policy trade-offs of the inflation and the exchange rate targeting in the low income countries estimated on the Mozambique data using (DSGE) model considering the sources of major exogenous shocks, and the financial development. On the other hand Chow et al. (2012) employs a dynamic stochastic general equilibrium-vector autoregressive (DSGE-VAR) approach to examine if the managed exchange-rate system outperform monetary Taylor in Singapore in terms of overall inflation volatility depending on many shocks . Also Huseynov (2010) estimated a small open economy using DSGE model taking in consideration the regime 
switches from exchange rate targeting to (IT) with flexible exchange rate . They also investigate the main driving forces of business cycles of the main macroeconomic variables. In this paper a common features with the Armenian economy are taken into consideration. First the importance of the remittance inflow as mentioned previously. Second considering the unit labor cost of the imported firms in their pricing decision that implies a low responsive of the imported good to the real exchange rate movements than in the standard models with nominal rigidities. The paper compares the economic volatility and the welfare in Tunisia of the managed versus flexible exchange rate, the Consumer Price Index (CPI) versus domestic (IT), the flexible versus the strict IT, the domestic versus the CPI Taylor rule regime.

The optimal regime is the one that stabilizes the economy face to many shocks and minimize the output, the exchange rate and the inflation's volatility, leading to a lower social loss. Some authors like Svensson (2000) suggested the flexible CPI (IT), because it stabilizes the output, the inflation and the real exchange rate. This model differs from the one of Svensson (2000) as it depends on the analyze of the impacts of different exchange rate regimes; leading to policy advice depending on the source and nature of the disturbances. The best reaction in terms of welfare is considered with the different monetary policies rules. It is revealed that the social loss is higher with the managed exchange rate than the flexible exchange rate regime for all the shocks, and that the CPI inflation outperforms the domestic (IT).At the end, the strict targeting is superior to the flexible (IT)except for the foreign inflation and the domestic interest rate. The paper is structured as follows. Section 2 describes the methodology. Section 3 illustrates the model's behavior face to shocks and evaluates the effect of these shocks conditional on the different monetary policy regimes. Section 4 displays the policy simulations results; finally section 5 summarizes the results.

\section{The Model Environment}

The design of the model builds upon Palma \&Portugal (2014) who referred to Gali \& Monacelli (2005), Justiniano \& Preston $(2010)^{1}$. This part of the thesis will consider a small open economy like Tunisia with some specifications like the adjustment costs, the habit formation to capture the inertia in the consumption, and the indexation of the prices. The utility function of the foreign household is given by:

$$
E_{t} \sum_{i=0}^{n} \beta^{i}\left\{\frac{e^{-\xi}\left(C_{t}^{*}-h C_{t-1}^{*}\right)}{1-\sigma}-x \frac{N_{t+i}^{1+\eta *}}{1-\eta}\right\}
$$

where $\beta$ is the discount factor, $\zeta_{t}$ is an exogenous stochastic variable. It designs the consumption or the investment preference parameter for the foreign household. It is also called remittance parameter .The utility is modified by adding this parameter because the existence of a large tunisian diaspora who are interested to remit income to Tunisia. $\mathrm{N}_{\mathrm{t}}$ denotes the labor supply. $\eta$ is the inverse elasticity of labor supply. The CPI inflation is given by $\pi_{\mathrm{t}}=\ln p_{\mathrm{t}}-\ln p_{\mathrm{t}-1}$. In this paper, the law of one price (LOP) is considered for the export sector however there is an incomplete pass-through in the import sector (LOP gap). The assumption of a complete international financial markets and a perfect capital mobility concerning the risk sharing justify the existence of a large Tunisian Diaspora. In this context the intertemporal optimality condition for the domestic household is equated to the one of foreign household. After some modifications at time $t+1$ the consumption equation is defined as follow:

$$
c_{t}=h c_{t-1}-\frac{1-h}{\sigma} r r_{t}+y_{t+1}^{*}-h y_{t}^{*}+\frac{1-h}{\sigma} q_{t+1}+\frac{1-h}{\sigma} \xi_{t+1}
$$

Where $c_{t}$ is the consumption, $h \in(0,1)$ represents the external habit formation for the household, $q_{t}$ is the real exchange rate, $\mathrm{y}_{\mathrm{t}}^{*}$ is the foreign output, $\sigma$ is the inverse elasticity of intertemporal substitution. By assuming the complete markets at the international level, the real uncovered interest parity condition is given by:

$$
q_{t}=E_{t} q_{t+1}-r r_{t}+r r_{t}^{*}-\left(\xi_{t}-\xi_{t+1}\right)
$$

that depends on the current real interest rate differentials as well as the remittance inflows. Where $r r_{t}=i_{t}-\pi_{t+1}$ is the domestic CPI based real interest rate and $r r_{t}^{*}=i_{t}^{*}-\pi_{t+1}^{*}$ is the foreign real interest rate.Turning to firms, there is a continuum of monopolistically-competitive identical firms that produce a good with a technology represented by the production function $Y_{t}(j)$.The latter depends on the labor supply Nt and the total productivity $z_{t}=\log \left(Z_{t}\right)$ and follows an $\operatorname{AR}(1)$ process where $0 \leq \rho_{z} \leq 1$ is a

\footnotetext{
${ }^{1}$ For more detail see also the paper "A New Keynesian Model of the Armenian Economy” of Ashot Mkrtchyan, Era DablaNorris, and Ara Stepanyan
} 
persistence parameter of the productivity and $\xi_{t}^{Z}$ is an iid preference shock. Moving to price setting part of the model, it is worth stating that the monopolistic firms fix prices in a Calvo manner in the domestic good market.Only $1-\theta_{h}$ of the domestic firms can optimally reset the prices while $\theta_{h}$ cannot in every time $t$. Each period,the optimizing firms set the price level $\bar{P}_{\mathrm{t}}$. As it is suggested by Svensson (2000), the presence of the adjustment cost and the habit formation can lead to a partial price adjustment which includes the backward looking component in the equation of the domestic inflation or the home Philips IS curve.

$$
\pi_{t}^{h}=\beta_{h} \pi_{t-1}^{h}+\left(1-\beta_{h}\right) \beta E_{t} \pi_{t+1}^{h}+\lambda_{\pi h} m c_{t} \text { where } 0<\beta_{h}<1
$$

In this case $\lambda_{\pi}{ }^{\mathrm{h}}$ is the coefficient on marginal cost in the IS curve, $\theta_{\mathrm{h}}$ represents the degree of rigidity when setting price, $\mathrm{mc}_{\mathrm{t}}$ designs the deviation of the marginal cost from the steady state. Concerning the import good sector part of the model. The price setting behavior for the domestic importers follow the same calvo procedure assuming that only $1-\theta_{\mathrm{m}}$ of importers who change their prices while $\theta_{\mathrm{m}}$ cannot. The assumption in this case is that the unit labor cost in domestic economy plays an important task in setting the price of importers firms. Concerning the supply part of the model .The latter describes the inflation dynamics and the marginal cost. The real marginal cost of the importer companies illustrates the mechanism of the incomplete pass-trough of the import price implying an important shifts in the nominal and the real exchange rates which affects in return the consumption, the employment and the price level. The imported goods inflation equation is added with the adjustment cost and the habit formation similarly to the case of home goods inflation equation as follow:

$$
\pi_{t}^{m}=\beta_{m} \pi_{t-1}^{m}+\left(1-\beta_{m}\right) \beta E_{t} \pi_{t+1}^{m}+\lambda_{\pi m} \psi_{t}^{m}, 0<\beta_{m}<1
$$

The overall inflation in the economy is obtained by log linearizing the definition of CPI:

$$
\pi_{t}=(1-\alpha) \pi^{h}+\alpha \pi^{m}
$$

As far as the equilibrium of the model is concerned, the good Market clearing condition for the domestic economy is expressed as follow:

$$
\begin{gathered}
y_{t}=d_{1} q_{t}-d_{2} \psi_{t}+\left(k_{1}+k_{2}\right) c_{t}+\left(1-k_{1}-k_{2}\right) y_{t}^{*} \\
d_{1}=\frac{k_{1} a \gamma}{1-\gamma}-\mathrm{a} k_{2}+\frac{\left(1-k_{1}-k_{2}\right) a^{*}}{1-\gamma} \text { and } d_{2}=\frac{k_{1} a \gamma}{1-\gamma}-\mathrm{a} k_{2}+\frac{\left(1-k_{1}-k_{2}\right) \gamma a^{*}}{1-\gamma}
\end{gathered}
$$

Where $\mathrm{k}_{1}$ is the part of the domestic consumption to GDP , $\mathrm{k}_{2}$ is the fraction of the imported good for the domestic goods .

When it comes to monetary policy,as the Tunsian economy is trying to follow the inflation targeting procedure,a simple, well understood rule of monetary policy is used rather than the optimal rule under commitment and a discretionary rule. After the reform of 1986, the behavior of the monetary policy has changed. For example there is a shift from the direct discretionary instruments to the intervention in the monetary market via the interest rate Chockri \& Frihka (2011).They noticed that Tunisia tend to a complete flexibility of the exchange rate as well as the (IT). In this context Leitemo (1999) insisted that that there are advantages in choosing a specific interest rate rule instead of letting the monetary authority discretionarily decide on the (IT) policy. In this case a Taylor rule is adopted with the extension of nominal exchange rate. However ,there is another specificity added which embodies a forward looking dimension. The monetary rule illustrates the responses of central bank that sets its policy rate to adjust for deviations of the expected CPI inflation, exchange rate and output changes from the target levels. Chockri \&Frihka (2011) elucidated that the inflation anticipation is crucial to the central bank because of the delay of the monetary policy transmission on this variable. That is why the central bank's decision must rely on the forecasted inflation and not on the past one. Rudebush \& Svensson (1998) found that inflation forecasts are central for good policy rules under (IT). They discovered that some simple instrument and targeting rules including inflation forecasts minimize better the loss function than the other policy rules representing the (IT).In this context, Ben Hadj Boubaker (2011) clarified that when the imperfect control of inflation is a hindrance to inflation targeter to be transparent,the central bank should adopt a forward -looking perspective by targeting the inflation forecast as follow:

$$
i_{t}=\rho_{i} i_{t-1}+\left(1-\rho_{i}\right)\left(\rho_{\pi} \pi_{t+1}+\rho_{y} y_{+} \rho_{s} d_{s}\right)+\epsilon
$$

where $\epsilon$ is the exogenous process of the domestic interest rate .It captures deliberate decisions to deviate temporarily from its systematic rule, $\rho_{\mathrm{i}}$ is the smoothness of the interest rate by the central bank, $\rho_{\pi}$ is the coefficient that indicates the reaction of the interest rate to the overall inflation good, $\rho_{y}$ is the response of the central bank to the change in the output, $\rho_{\mathrm{s}}$ the response of central bank to a change in the nominal exchange rate, $d s$ is the movement of the nominal exchange rate. The exogenous process is defined as follow. The domestic productivity take this form $\mathrm{zt}=\rho_{\mathrm{z}}{ }^{*} \mathrm{z}{ }_{\mathrm{t}-1}+\mathcal{E}_{\mathrm{t}}{ }^{2}$ where $\varepsilon_{\mathrm{t}}{ }^{2} \quad$ (epsz) is the domestic 
productivity shock. The world output is expressed as $\mathrm{y}_{\mathrm{t}}^{*}=\rho_{\mathrm{y}^{*}} \mathrm{y}_{\mathrm{t}-1+{ }_{\mathrm{t}}} \varepsilon^{\mathrm{y}^{*}}$ where $\varepsilon_{\mathrm{t}} \mathrm{y}^{*}$ (epsystar) is the foreign output

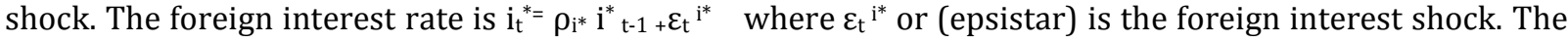

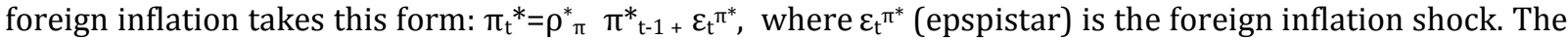
domestic interest rate is defined as follow : $\epsilon=\rho_{\epsilon}{ }^{*} \epsilon_{t-1}+\varepsilon_{t} \epsilon^{\epsilon}$, where $\varepsilon_{t}{ }^{\epsilon}$ (epsei) is the domestic interest rate shock .Finally the remittance or the preference of the foreign household is defined as : $\zeta_{t}=\rho_{\zeta} \zeta_{t-1}+\varepsilon \zeta_{t}$ where $\varepsilon^{\zeta_{t}}$ (epszeta) is the remittance shock. These shocks are independent and identically distributed (iid) with zero mean and standard deviation.

\section{The welfare criterion}

To explain the welfare criterion, this study refer to the one of Parrado (2004) and Svensson (2000).In fact Rudebusch \& Svensson(1998) précised that by a targeting rule(one or several variables), the central bank must minimize a loss function that is increasing in the deviation between a target variable and the target level for this variable. According to Svensson, the best way to minimize a loss function is to respond optimally with the instrument to the determinants of the state variables of the economy. It is crucial to analyze the welfare of different regime of the monetary policies ${ }^{2}$ to evaluate the expected social loss. In this case, the social loss depends on the output, the inflation and the real exchange rate's deviation from their steady state. The assumption on the social loss is defined as an approximation of some aggregate of the welfare of the consumer-producers. It is obtained from the utility function of the representative agent. The welfare criterion of the home country is presented as:

$$
\mathrm{L}_{\mathrm{t}}=\Psi_{\pi^{\mathrm{h}}}^{\mathrm{h}} \pi_{\mathrm{h}, \mathrm{t}^{2}}+\mu_{\pi^{c}}{ }^{\mathrm{s}} \pi_{\mathrm{t}}{ }^{2}+\lambda \mathrm{yt}^{2}+\mu_{\mathrm{q}} \mathrm{qt}^{2}
$$

After introducing the unconditional expectation, the loss function becomes:

$$
\mathrm{E}\left(\mathrm{L}_{\mathrm{t}}\right)=\Psi_{\pi^{\mathrm{h}}}^{\mathrm{h}} \operatorname{var}\left(\pi_{\mathrm{h}, \mathrm{t}}\right)+\mu_{\pi^{\mathrm{c}}}^{\mathrm{c}} \operatorname{var}\left(\pi_{\mathrm{t}}^{\mathrm{c}}\right)+\lambda \operatorname{var}\left(\mathrm{y}_{\mathrm{t}}\right)+\mu_{\mathrm{q}} \operatorname{var}\left(\mathrm{q}_{\mathrm{t}}\right)
$$

Here $\operatorname{var}\left(\pi_{\mathrm{h}, \mathrm{t}}\right), \operatorname{var}\left(\mathrm{q}_{\mathrm{t}}\right), \operatorname{var}\left(\mathrm{y}_{\mathrm{t}}\right)$ are the unconditional variances of the domestic inflation, the real exchange rate and the output gap . In this paper the following weights considered for the loss function are $\Psi_{\pi}^{\mathrm{h}}=1.5, \lambda$ $=0.5, \mu_{q}=0.5, \mu_{\pi}^{c}=1.5$, like those determined by Parrado(2004) in a small open economy like Chile.In general, the conclusion is approximate to the alternative reasonable parameter value.

The Model simulation: The quantitative simulation is analyzed to know how the (IT) and the taylor rule affect the business cycle dynamics with the DSGE model and compare their influence on the output, the inflation, and the exchange rates. In fact, the model considers six types of regimes. First the Strict vs the flexible domestic (IT) with both the flexible and the managed exchange rate ; the Strict vs the flexible CPI (IT) with both the flexible and the managed exchange rate; the taylor rule with both the CPI and the domestic inflation.

Calibration and parameterization: When it comes to the model parameterization, the parameter's value exhibited in the table 1, are collected from the traditional related literature and the current Tunisian data like the one of Jouini \& Rebei (2014) and Ben aissa \& Rebei (2012).The data are annually selected from 1980Q1 to 2011Q4. The considered variables are the overall or the CPI inflation(pi $) \pi_{t}$ defined in equation (6), the real exchange rate(q) detected in equation (3), the output(y) noticed in (7), the home good inflation $\pi_{t}^{h}(p i h)$ showed in (4), the nominal interest rate(i) observed in (8), the domestic real interest rate(rr) presented in (3). In this case the coefficients $\rho_{\pi^{\mathrm{h}}}{ }^{\mathrm{h}}, \rho_{\mathrm{y}}, \rho_{\mathrm{s}}$ and $\rho_{\mathrm{i}}$ are not estimated with the generalized method of moments (GMM) such as Parrado (2004). However, these values are determined from the litterature of the emergent countries like Armanian economy, Chile ,Turkey ,Brazil and the Tunisian data so as to obtain a performant result that is approximative to the Tunisian economy and to have an idea about the optimal regime in term of the welfare loss. The response of the central bank to the domestic inflation is given by $\rho_{\pi^{\mathrm{h}}}=1.5$. When $\rho_{\pi^{\mathrm{h}}}^{\mathrm{h}}>1.5$, this indicates that if the expected inflation rises, the central bank of Tunisia reacts by increasing the interest rate remarkably.While the weight associated to the output is not very significant ,it amounts to $\rho_{y}=0.25$. The response of the central bank to the CPI inflation is fixed to $\rho_{\pi}$ $=1.5$. The persistence parameter or the degree of smoothing of the domestic productivity is calibrated as $\rho_{\mathrm{z}}=0.80$, while the one of the foreign output corresponds to $\rho_{\mathrm{y}^{*}}=0.5$. For the foreign interest rate, it is equal to $\rho_{\mathrm{i}^{*}}=0.85$.

\footnotetext{
${ }^{2}$ see the User manual for optimal policy package of Michel Juillard 2011
} 
Table 1: Model parameter value

\begin{tabular}{llll}
\hline Parameter & value & Parameter & Value \\
\hline $\mathrm{k}_{1}$ & 0.63 & $\rho_{\mathrm{z}}$ & 0.80 \\
$\mathrm{k}_{2}$ & 0.17 & $\rho_{\mathrm{y}^{*}}$ & 0.5 \\
$\mathrm{k}_{3}$ & 0.16 & $\rho_{\mathrm{y}}$ & 0.25 \\
$\mathrm{~B}$ & 0.985 & $\rho_{\mathrm{i}^{*}}$ & 0.85 \\
$\beta_{\mathrm{h}}$ & 0.65 & $\rho_{\pi^{*}}$ & 0.5 \\
$\beta_{\mathrm{m}}$ & 0.45 & $\rho_{\zeta}$ & 0.8 \\
$\beta_{\mathrm{q}}$ & 0.25 & $\rho_{\mathrm{i}}$ & 0.5 \\
$\Sigma$ & 1 & $\eta$ & 1.45 \\
$\mathrm{H}$ & 0.5 & $\mathrm{a}$ & 1.25 \\
$\theta_{\mathrm{m}}$ & 0.75 & $\alpha_{\Psi}$ & 0,60 \\
$\theta_{\mathrm{h}}$ & 0.67 & $\alpha$ & 0.68 \\
& & $\mathrm{a}^{*}$ & 1.25 \\
\hline
\end{tabular}

On the other side, the foreign inflation persistent parameter is detected as $\rho_{\pi^{*}}=0.5$. The similar value holds for the domestic interest rate $\rho_{\mathrm{i}}=0.5$. Then comes the foreign preference which is designated to $\rho_{\zeta}=$ 0.8 . Finally the nominal exchange rate is picked as $\rho_{\mathrm{s}}=0.85$. So it is concluded that the tunisian central bank is interested in stabilizing the inflation through the inflation target and the nominal exchange rate, without paying attention to the output stabilization where $\rho_{\mathrm{y}}=0.25$.The quarterly discount factor is $\beta=0.985$. The simulation compares rules with $\rho_{y}=0$ which corresponds to the strict (IT) against $\rho_{y}=0.25$ which explains the flexible (IT)and $\rho_{s}=0$ against $\rho_{s}=0.85$ which illustrates the flexible against the managed exchange rate regime. Turning to the inverse elasticity of intertemporal substitution in consumption $\sigma$ between the consumption of today and tomorrow, it is set to $1^{3}$.On the other hand, the steady parameters are parametrized as follow: The ratio of government expenditure to GDP is given by $\mathrm{k}_{3}=0,16$; The ratio of the exports to GDP amounts to 0 . 3.The imported good distribution share in the total demand is calculated as $\mathrm{k}_{2}=0.17$.The coefficient of the share of nominal marginal costs in total costs of the importing firms is set to $\alpha_{\psi}=0,60$.The ratio of the private expenditure to GDP or the share of domestic consumption to GDP is calibrated to $\mathrm{k}_{1}=0,63$.The share of the imported goods in the consumption $(\alpha)$ or the degree of openness is fixed to 0,68 . When taking into account the stochastic process, it is noted that the standard deviation of the domestic productivity, the foreign output, the foreign interest rate, the preference, the foreign inflation and the domestic interest rate are chosen as follow: $\sigma_{\mathrm{z}}=0,01, \quad \sigma_{\mathrm{y}^{*}=0,01} \quad \sigma_{\mathrm{i}^{*}=0,01} \quad \sigma_{\zeta}=0,024 \quad \sigma_{\pi^{*}}=0,01$ $\sigma_{\epsilon}=0,005$.

\section{Results}

In this study ,six types of shocks are considered : the productivity, the world output, the foreign inflation, the preference, the foreign interest rate and the domestic interest rate. Each shock is a first order exogenous process. To obtain a policy evaluation criterion, it is crucial to consider the unconditional standard deviation of the variables to each shock. The standard deviation is illustrated in the table 3 until 8. The impulse response function of the principal variables to the different shocks are considered for different types of inflation and exchange rate targeting regimes.

Flexible versus managed exchange rate: Figureures 1 until 6 report the impulse response function of the domestic(IT) in the case of flexible vs managed exchange rate while the figureures 7 to 12 replicate the impulse response function of the CPI (IT) in the same case. In this case the blue line defines the flexible Exchange rate while the black line designs the managed exchange rate. Under the managed exchange rate regime, the monetary authority focus on stabilizing the exchange rate that is $\left(\rho_{s} \in(0, \infty)\right.$. In most of the cases, the domestic interest rate (i) increases partially under this regime.

\footnotetext{
${ }^{3}$ (Smets and Wouters, 2003) estimate an intertemporal elasticity of substitution equal to 0.7 for the Euro zone.(Bergin, 2006) estimate a value of nearly 1 for the United states. (Adjémian et al. 2004) obtained a values near to one for the United States as well as for the Euro zone. (Juillard et al. 2006) find a value of 0.8 for the United States .A unit value is current in the literature (Ireland, 2004).
} 
Regime I : Flexible vs managed exchange rate: Domestic inflation targeting

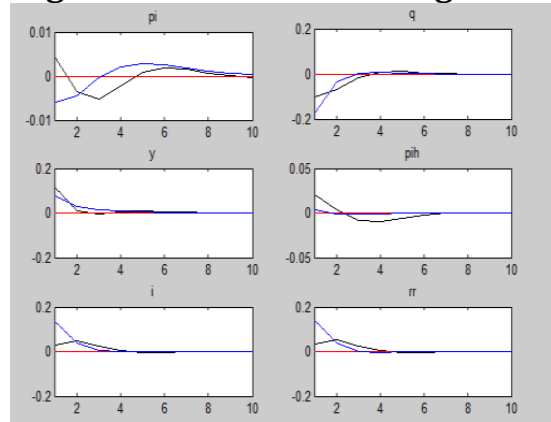

Figure 1: orthogonalized shock to $\varepsilon_{\mathrm{t}} \mathrm{y}^{*}$

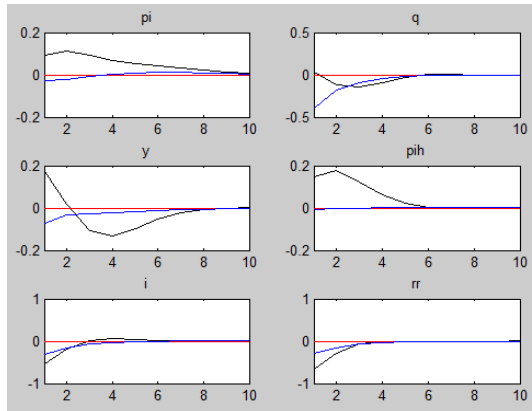

Figure 4: orthogonalized shock to $\varepsilon \pi^{*}$

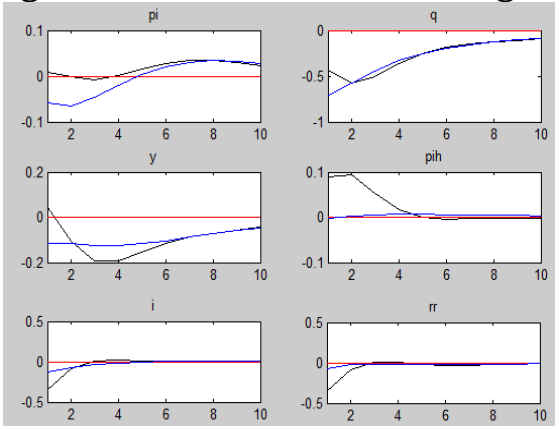

Figure 2: orthogonalized shock to $\varepsilon \zeta_{\mathrm{t}}$

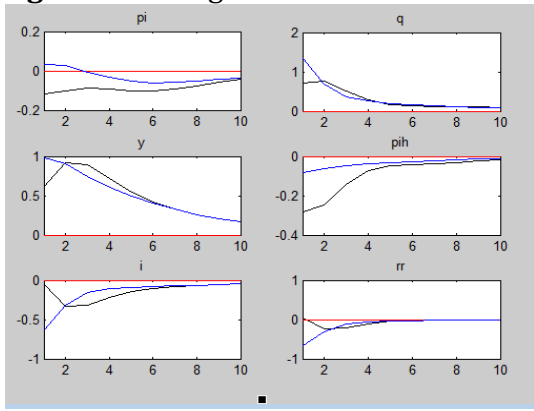

Figure 1 : orthogonalized shock to $\varepsilon_{\mathrm{t}^{\mathrm{z}}}$

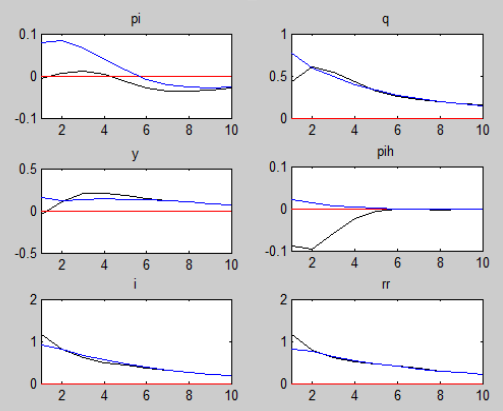

Figure 3: orthogonalized shock to $\varepsilon_{\mathrm{i}^{*}}$

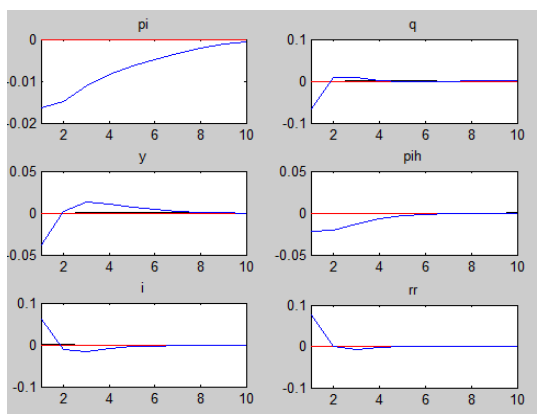

Figure 2: orthogonalized shock to $\varepsilon_{t^{\epsilon}}$

Regime II: Flexible vs managed exchange rate : CPI inflation targeting

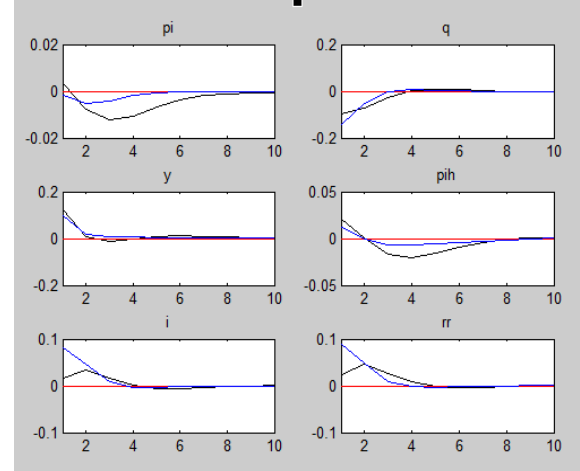

Figure 7: orthogonalized shock to $\varepsilon_{\mathrm{t}^{\mathrm{y}}}$

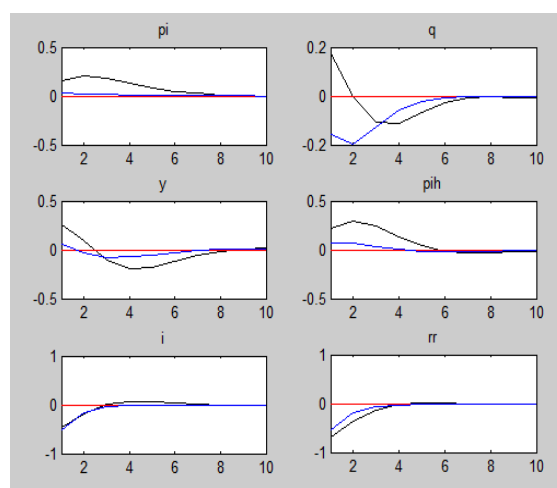

Figure 10: orthogonalized shock to $\varepsilon \pi^{*}$

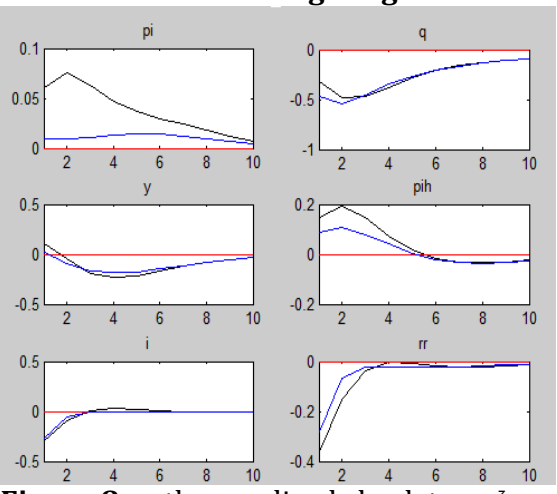

Figure 8: orthogonalized shock to $\varepsilon \xi_{t}$

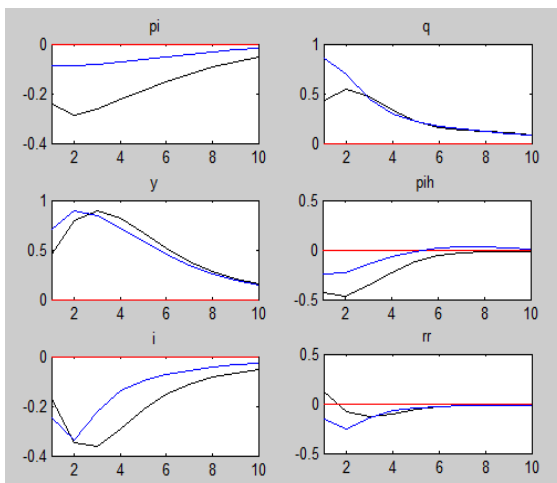

Figure 11: orthogonalized shock to $\varepsilon_{t}{ }^{2}$

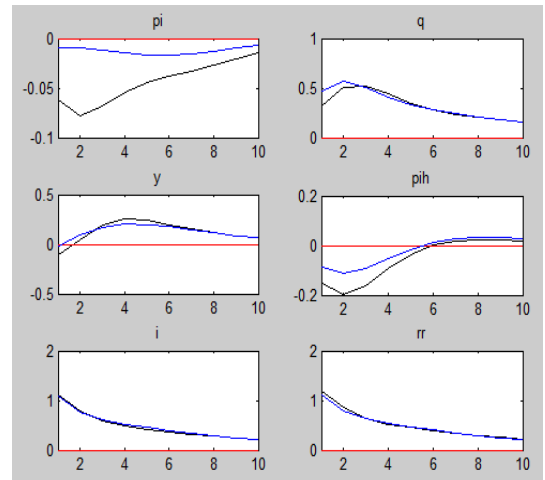

Figure 9: orthogonalized shock to $\varepsilon$ i*
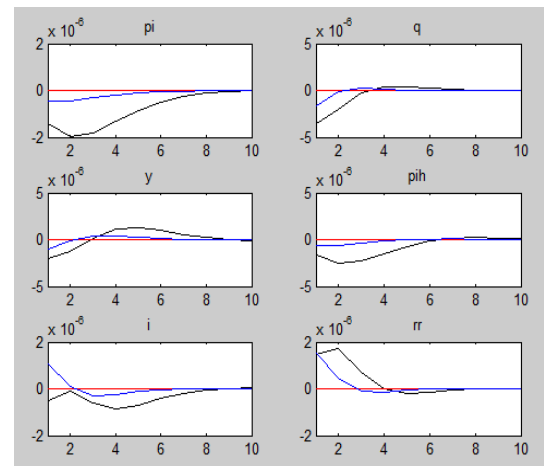

Figure 12: orthogonalized shock to $\varepsilon_{\mathrm{t}}^{\epsilon}$

The nominal rigidities which is the origin of the ascension in the real interest rate ( $\mathrm{rr}$ ), causes a depreciation of the output(y). According to Parrado (2004) this result is consistent with the conventional wisdom. While under the flexible exchange rate, the central bank adjusts the nominal interest rate to the change of the output and the inflation only that is $\rho_{\mathrm{s}}=0$. However under the flexible or the managed exchange rate regime, the domestic interest rate( $i)$ is linked to the foreign interest rate $\operatorname{shock}\left(\varepsilon i^{*}\right), o r$ any other foreign disturbance. That is, when there is a foreign interest rate $\operatorname{shock}\left(\varepsilon_{i^{*}}\right)$, there is a depreciation of 
the nominal interest rate(i) with all the foreign shocks. This is consistent with the result of Parrado(2004)except with the foreign inflation $\operatorname{shock}\left(\varepsilon \pi^{*}\right)$. Moreover ,for both the managed and the flexible exchange rate regime and with the foreign interest shock $\left(\varepsilon \mathrm{i}^{*}\right)$, the CPI inflation( $\left.\pi=\mathrm{pi}\right)$ is depreciated. The table 3 to 8 report that for the majority of the shocks, the unconditional standard deviation of the output $\left(y_{t}\right)$, the CPI inflation volatility $(\pi)$ and the domestic inflation $(\pi \mathrm{h}=$ pih)are higher in the managed than the flexible exchange rate regime. As Peiris \&Saxegaard (2007), it is noticed that the exchange rate peg has a significant impact on the CPI inflation volatility $(\pi)$. Nevertheless, this is not the case of the nominal exchange rate $\left(\mathrm{q}_{\mathrm{t}}\right)$ which shows a small volatility in the managed exchange rate regime compared to the flexible one with nearly all the shocks.

Table2: The welfare losses

\begin{tabular}{|c|c|c|c|c|c|c|}
\hline & $\begin{array}{l}\text { Domestic } \\
\text { interest } \\
\text { rate } \varepsilon_{\mathrm{t}}{ }^{\epsilon}\end{array}$ & $\begin{array}{l}\text { Productiv } \\
\text { ity } \varepsilon^{z}\end{array}$ & $\begin{array}{l}\text { World } \\
\text { output } \\
\varepsilon_{\mathrm{t}} \mathrm{y}^{*}\end{array}$ & $\begin{array}{l}\text { Foreign } \\
\text { inflation } \\
\varepsilon \pi^{*} \\
\end{array}$ & $\begin{array}{l}\text { Preference } \\
\varepsilon \zeta_{t}\end{array}$ & $\begin{array}{l}\text { Foreign } \\
\text { interest rate } \\
\varepsilon_{\mathrm{i}^{*}} \\
\end{array}$ \\
\hline \multicolumn{7}{|l|}{ Strict domestic IT } \\
\hline Flexible exchange rate & 0.001 & 0.002 & 0.001 & 0.011 & 0.000 & 0.006 \\
\hline Managed exchange rate & 0.002 & 0.989 & 0.006 & 0.058 & 0.563 & 0.746 \\
\hline \multicolumn{7}{|l|}{ Flexible domestic IT } \\
\hline Flexible exchange rate & 0.001 & 1.729 & 0.003 & 0.003 & 0.052 & 0.078 \\
\hline \multicolumn{7}{|l|}{ Strict CPI IT } \\
\hline Flexible exchange rate & 0.002 & 0.008 & 0.000 & 0.032 & 0.000 & 0.000 \\
\hline \multicolumn{7}{|l|}{ Flexible CPI IT } \\
\hline Flexible exchange rate & 0.001 & 1.716 & 0.006 & 0.003 & 0.063 & 0.092 \\
\hline Managed exchange rate & 0.002 & 2.465 & 0.014 & 0.053 & 0.576 & 0.786 \\
\hline $\begin{array}{l}\text { Tayor rule domestic inflation } \\
\mathrm{i}_{\mathrm{t}}=1.5 \pi \mathrm{t}^{\mathrm{h}}+0.25 \mathrm{yt} \\
\text { Taylor rule CPI inflation }\end{array}$ & -0.000 & 1.730 & 0.003 & 0.003 & 0.052 & 0.077 \\
\hline $\mathrm{i}_{\mathrm{t}}=1.5 \pi_{\mathrm{t}}+0.25 \mathrm{yt}$ & 0.000 & 1.709 & 0.004 & 0.0039 & 0.064 & 0.092 \\
\hline
\end{tabular}

Table 3: Unconditional standard deviation of the productivity shock $\left(\operatorname{epsz}=\varepsilon_{\mathrm{t}}^{\mathrm{z}}\right)$

\begin{tabular}{|c|c|c|c|c|c|c|}
\hline Targeting case / variables & $\pi^{c_{t}}$ & $\mathbf{q}_{\mathrm{t}}$ & $\mathrm{y}_{\mathrm{t}}$ & $\pi^{h_{t}}$ & $\mathbf{i}_{\mathbf{t}}$ & $\mathbf{r r}_{\mathbf{t}}$ \\
\hline \multicolumn{7}{|l|}{ Strict domestic IT } \\
\hline Flexible exchange rate & 0.132 & 1.812 & 1.892 & 0.049 & 0.964 & 1.045 \\
\hline Managed exchange rate & 0.179 & 1.212 & 1.852 & 0.427 & 0.443 & 0.362 \\
\hline \multicolumn{7}{|l|}{ Flexible domestic IT } \\
\hline Flexible exchange rate & 0.124 & 1.599 & 1.850 & 0.115 & 0.696 & 0.703 \\
\hline Managed exchange rate & 0.215 & 1.233 & 1.834 & 0.405 & 0.489 & 0.319 \\
\hline $\begin{array}{l}\text { Strict CPI IT } \\
\text { Flexible exchange rate }\end{array}$ & 0.000 & 1.490 & 1.855 & 0.216 & 0.611 & 0.611 \\
\hline Managed exchange rate & 0.286 & 1.079 & 1.900 & 0.630 & 0.260 & 0.253 \\
\hline \multicolumn{7}{|l|}{ Flexible CPI IT } \\
\hline Flexible exchange rate & 0.085 & 1.348 & 1.846 & 0.312 & 0.490 & 0.423 \\
\hline $\begin{array}{l}\text { Managed exchange rate } \\
\text { Tavlor rule domestic inflation }\end{array}$ & 0.276 & 1.120 & 1.856 & 0.532 & 0.418 & 0.265 \\
\hline $\begin{array}{l}\mathrm{i}_{\mathrm{t}}=1.5 \Pi_{\mathrm{t}}^{\mathrm{h}}+0.5 \mathrm{y}_{\mathrm{t}} \\
\text { Taylor rule CPI inflation }\end{array}$ & 0.122 & 1.570 & 1.846 & 0.129 & 0.649 & 0.647 \\
\hline $\mathrm{i}_{\mathrm{t}}=1.5 \Pi_{\mathrm{t}}+0.5 \mathrm{y}_{\mathrm{t}}$ & 0.078 & 1.398 & 1.844 & 0.275 & 0.564 & 0.501 \\
\hline
\end{tabular}

This finding is in line with the result of Gali \& Monacelli (2005). Turning to the table 2 , the latter illustrates the welfare loss of a different monetary policies associated with many shocks.It is concluded from this table that the flexible dominates the managed exchange rate for both the CPI and the domestic (IT) regime because the welfare loss of the managed exchange rate is higher with almost all the shocks. (Parrado, 2004) confirmed the conventional wisdom that the flexibility is better in the case of foreign and real exchange rate shocks, while pegging is preferable in the case of nominal shocks. To confirm our result, it is worth stating the finding of Gali \&Monacelli( 2005) concerning the welfare loss of the exchange rate peg which is higher than the taylor rule. 
Domestic vs CPI inflation targeting: According to Svensson (2000), the difference between the CPI and the domestic inflation can be detected when the direct exchange rate channel is more noticeable in the CPI targeting. Figureures 13 to 24 exhibit the impulse response functions comparing the CPI vs the domestic(IT) with respectively the flexible and the managed exchange rate. In this case the blue line illustrates the CPI (IT) while the black line designs the domestic(IT). It is worth noticing that in the case of the managed exchange rate, it is not appropriate to compare between the CPI and the domestic (IT) since the difference of the variable volatilities is negligible Parrado(2004). In contrast to the flexible exchange regime which is a suitable regime for comparison. In fact with this regime, targeting the CPI is equivalent to targeting both domestic inflation and nominal exchange rate. Parrado (2004) highlighted that the domestic inflation target favorizes the movement of the exchange rate in response to shocks to stablize the output.

\begin{tabular}{|c|c|c|c|c|c|c|}
\hline Targeting case / variables & $\pi^{c_{t}}$ & $\mathbf{q}_{\mathrm{t}}$ & $\mathbf{y t}_{\mathrm{t}}$ & $\pi^{\mathbf{h}_{t}}$ & $\mathbf{i}_{\mathrm{t}}$ & $\mathbf{r r}_{\mathrm{t}}$ \\
\hline \multicolumn{7}{|l|}{ Strict domestic IT } \\
\hline Flexible exchange rate & 0.013 & 0.127 & 0.113 & 0.031 & 0.063 & 0.07 \\
\hline Managed exchange rate & 0.017 & 0.090 & 0.140 & 0.047 & 0.039 & 0.037 \\
\hline \multicolumn{7}{|l|}{ Flexible domestic IT } \\
\hline Flexible exchange rate & 0.026 & 0.094 & 0.094 & 0.033 & 0.090 & 0.10 \\
\hline Managed exchange rate & 0.013 & 0.116 & 0.121 & 0.035 & 0.054 & 0.05 \\
\hline \multicolumn{7}{|l|}{ Strict CPI IT } \\
\hline Flexible exchange rate & 0.017 & 0.096 & 0.135 & 0.046 & 0.039 & 0.041 \\
\hline Managed exchange rate & 0.030 & 0.066 & 0.162 & 0.066 & 0.025 & 0.023 \\
\hline \multicolumn{7}{|l|}{ Flexible CPI IT } \\
\hline Flexible exchange ra & 0.025 & 0.147 & 0.100 & 0.035 & 0.076 & 0.09 \\
\hline Managed exchange rate & 0.014 & 0.102 & 0.131 & 0.040 & 0.045 & 0.047 \\
\hline \multicolumn{7}{|l|}{ Taylor rule domestic inflation } \\
\hline $\mathrm{i}_{\mathrm{t}}=1.5 \Pi_{\mathrm{t}}^{\mathrm{h}}+0.5 \mathrm{y}_{\mathrm{t}}$ & 0.019 & 0.188 & 0.078 & 0.019 & 0.138 & 0.15 \\
\hline $\begin{array}{l}\text { Taylor rule CPI inflatic } \\
i_{t}=1.5 \Pi_{t}+0.5 y_{t}\end{array}$ & & & & & & \\
\hline $\mathrm{i}_{\mathrm{t}}=1.5 \Pi_{\mathrm{t}}+0.5 \mathrm{y}_{\mathrm{t}}$ & 0.021 & 0.172 & 0.085 & 0.025 & 0.124 & .132 \\
\hline
\end{tabular}

As it is remarqued in the tables 3 to 8 that for most of the shocks,the volatility of most of the variables under the flexible exchange rate regime is higher in the CPI than the domestic (IT) especially for the domestic inflation $\left(\pi_{\mathrm{h}}\right)$ and the output $(\mathrm{y})$. In contrast to the volatility of the real exchange rate variable $\left(\mathrm{q}_{\mathrm{t}}\right)$ which is rather higher with the domestic inflation targeting regime.This result is conform to the one of Parrado (2004). In addition it is discovered from the table 2 that the welfare is preferable in the CPI than under the domestic (IT)because the social loss is higher in the domestic(IT). This preference for the CPI is justified by the use of 27 inflation targeters of the (CPI). As their operational target, they especially use the headline rather than the core measure because it is largely for practical and operational reasons Hammond (2012). Independently of the nature of the shock or the targeting case ,the result found is in contradiction with the study of Parrado (2004). On the other hand, Ben aissa \&Rebei (2012) found that the welfare gains in targeting sectoral rather than CPI inflation.

Flexible versus strict inflation targeting: According to Ball (1997) the strict inflation is manifested when the policy minimizes the variance of inflation from its target. The latter occurs when the monetary policy aims to stabilize only the inflation and the exchange rate without taking into consideration the effects on the output $\left(\rho_{\mathrm{y}}=0\right)$ Svensson(2000).In this case, the direct exchange rate channel offers a potentially effective inflation stabilization at a relatively short horizon Svensson (1997). According to Svensson (2000) this may require activism and frequent adjustment of the monetary policy instrument with the variability of the macro variables other than the inflation. However, the flexible inflation targeting is achieved when the central bank aims to stabilize the output, the exchange rate and the inflation. In this case there are a less activism and a less variability in the macro variables except for the inflation. For more detail of the reaction of the macro variable face to the different shock's movement under the flexible exchange rate,figureures 25 to 36 compare the impulse response functions of the flexible vs strict domestic and CPI(IT). In the figures 25 to 30 the Blue line indicates the flexible CPI inflation targeting while the Black line determines the strict CPI inflation targeting . 
Table5: Unconditional standard deviation for foreign inflation shock(epspistar $\left.=\varepsilon_{t^{*}}{ }^{*}\right)$

\begin{tabular}{|c|c|c|c|c|c|c|}
\hline Targeting case/variables & $\pi^{c_{t}}$ & $\overline{\mathbf{q}_{\mathbf{t}}}$ & $y_{t}$ & $\pi^{\mathbf{h}_{\mathrm{t}}}$ & $\mathbf{i}_{\mathbf{t}}$ & $\mathbf{r r}_{\mathbf{t}}$ \\
\hline \multicolumn{7}{|l|}{ Strict domestic IT } \\
\hline Flexible exchange rate & 0.036 & 0.444 & 0.095 & 0.023 & 0.348 & 0.329 \\
\hline Managed exchange rate & 0.034 & 0.293 & 0.137 & 0.104 & 0.510 & 0.536 \\
\hline Flexible domestic IT & & & & & & \\
\hline Flexible exchange rate & 0.028 & 0.419 & 0.086 & 0.021 & 0.379 & 0.363 \\
\hline Managed exchange rate & 0.032 & 0.309 & 0.116 & 0.087 & 0.488 & 0.512 \\
\hline Strict CPI IT & & & & & & \\
\hline Flexible exchange rate & 0.005 & 0.354 & 0.096 & 0.060 & 0.437 & 0.439 \\
\hline $\begin{array}{l}\text { Managed exchange rate } \\
\text { Flexible }\end{array}$ & 0.075 & 0.246 & 0.189 & 0.160 & 0.527 & 0.587 \\
\hline Flexible exchange rate & 0.013 & 0.379 & 0.084 & 0.040 & 0.413 & 0.410 \\
\hline Managed exchange rate & 0.059 & 0.274 & 0.143 & 0.122 & 0.497 & 0.543 \\
\hline $\begin{array}{l}\text { Taylor rule domestic inflation } \\
\mathrm{i}_{\mathrm{t}}=1.5 \Pi_{\mathrm{t}}^{\mathrm{h}}+0.5 \mathrm{y}_{\mathrm{t}} \\
\text { Taylor rule CPL inflation }\end{array}$ & 0.038 & 0.414 & 0.078 & 0.014 & 0.392 & 0.381 \\
\hline $\mathrm{i}_{\mathrm{t}}=1.5 \Pi_{\mathrm{t}}+0.5 \mathrm{y}_{\mathrm{t}}$ & 0.017 & 0.382 & 0.083 & 0.0418 & 0.394 & 0.397 \\
\hline
\end{tabular}

Table 6: Unconditional standard deviation for preference shock (epszeta $\left.=\varepsilon \zeta_{t}\right)$

\begin{tabular}{|c|c|c|c|c|c|c|}
\hline Targeting case /variables & $\pi^{c_{t}}$ & $\mathbf{q}_{\mathrm{t}}$ & $\mathbf{y}_{\mathbf{t}}$ & $\pi^{h_{t}}$ & $\mathbf{i}_{\mathbf{t}}$ & $\mathbf{r r}_{\mathrm{t}}$ \\
\hline \multicolumn{7}{|l|}{ Strict domestic IT } \\
\hline Flexible exchange rate & 0.114 & 1.182 & 0.339 & 0.070 & 0.088 & 0.093 \\
\hline Managed exchange rate & 0.081 & 1.003 & 0.394 & 0.205 & 0.312 & 0.346 \\
\hline \multicolumn{7}{|l|}{ Flexible domestic IT } \\
\hline Flexible exchange rate & 0.108 & 1.175 & 0.339 & 0.069 & 0.086 & 0.093 \\
\hline Managed exchange rate & 0.081 & 1.027 & 0.368 & 0.171 & 0.268 & 0.285 \\
\hline Strict CPI IT & & & & & & \\
\hline Flexible exchange rate & 0.015 & 1.040 & 0.3758 & 0.173 & 0.204 & 0.205 \\
\hline $\begin{array}{l}\text { Managed exchange rate } \\
\text { Flexible CPI IT }\end{array}$ & 0.156 & 0.929 & 0.5126 & 0.371 & 0.303 & 0.424 \\
\hline Flexible exchange rate & 0.049 & 1.092 & 0.3470 & 0.115 & 0.132 & 0.117 \\
\hline Managed exchange rate & 0.109 & 0.964 & 0.4318 & 0.278 & 0.242 & 0.320 \\
\hline $\begin{array}{l}\text { Taylor rule domestic inflation } \\
\mathrm{i}_{\mathrm{t}}=1.5 \Pi_{\mathrm{t}} \mathrm{h}^{\mathrm{h}}+0.5 \mathrm{y}_{\mathrm{t}}\end{array}$ & 0.126 & 1.152 & 0.3232 & 0.009 & 0.165 & 0.097 \\
\hline $\begin{array}{l}\text { Taylor rule CPI inflation } \\
\mathrm{i}_{\mathrm{t}}=1.5 \Pi_{\mathrm{t}}+0.5 \mathrm{y}_{\mathrm{t}}\end{array}$ & 0.049 & 1.095 & 0.3499 & 0.125 & 0.112 & 0.104 \\
\hline
\end{tabular}

Nevertheless in the figurers 31 to 36 , the blue line designs the flexible domestic (IT)while the black line displays the strict domestic(IT). The first observation that is elucidated is, regardless the type of regime and the shock, the majority of the volatility's variables are higher in the strict than the flexible case. For the majority of the shocks, there is a higher volatility of the output $\left(\mathrm{y}_{\mathrm{t}}\right)$ and the domestic inflation $\left(\pi^{\mathrm{h}}\right)$ especially with the strict (IT)regime for both the CPI or the domestic inflation. This result is in line with the one of Parrado( 2004). In contrast to the real exchange rate $\left(q_{t}\right)$, whose volatility is higher with the flexible (IT) in most of the cases. This finding matches the one of (Parrado, 2004)but differ to the one of Svenson (2000) who revealed that with the strict CPI(IT), the volatility of the exchange rate $\left(\mathrm{q}_{\mathrm{t}}\right)$ is important while in the flexible case, it recognizes a considerable stabilization . In fact, Svensson (2000) pointed out that the strict CPI (IT) is based on the direct exchange rate channel to stabilize the CPI inflation ( $\pi$ ) at a short horizon implying a high variability of the real exchange rate and the other variables. In this context Ball (1999) highlighted that in an open economy, the (IT) can be dangerous because of the effects of exchange rates on inflation through the import prices. This exchange rate is considered as the fastest channel from the monetary policy to the inflation. In this case, the (IT)is used aggressively.The large variation in the exchange rate implies a large output fluctuation through the IS curve.

There are some variables whose result is ambiguous like the CPI inflation ( $\pi$ ), the domestic interest rate( i) and the domestic CPI based real interest rate ( $\mathrm{rr}$ ). In terms of the welfare comparison,the Table 2 reports that the social loss is higher with the flexible than with the strict IT for the majority of the variables and the 
shocks except the foreign inflation $\varepsilon \pi^{*}$ and the domestic interest rate $\varepsilon_{\mathrm{t}}{ }^{\epsilon}$ shock. This finding is in contrast to the result detected by Parrado (2004) and Svensson (2000)when targeting inflation at a longer horizon.

\begin{tabular}{|c|c|c|c|c|c|c|}
\hline Targeting case / variables & $\pi^{c_{t}}$ & $\mathbf{q}_{\mathrm{t}}$ & $y_{t}$ & $\pi^{h_{t}}$ & $\mathbf{i}_{\mathbf{t}}$ & $\mathbf{r r}_{\mathbf{t}}$ \\
\hline \multicolumn{7}{|l|}{ Strict domestic IT } \\
\hline Flexible exchange rate & 0.122 & 1.310 & 0.408 & 0.083 & 1.703 & 1.641 \\
\hline Managed exchange rate & 0.186 & 1.085 & 0.564 & 0.386 & 1.772 & 1.931 \\
\hline \multicolumn{7}{|l|}{ Flexible domestic IT } \\
\hline Flexible exchange rate & 0.151 & 1.293 & 0.391 & 0.023 & 1.750 & 1.696 \\
\hline \multicolumn{7}{|l|}{ Strict CPI IT } \\
\hline Flexible exchange rate & 0.020 & 1.194 & 0.446 & 0.189 & 1.746 & 1.746 \\
\hline Managed exchange rate & 0.161 & 1.093 & 0.574 & 0.382 & 1.816 & 1.936 \\
\hline $\begin{array}{l}\text { Flexible CPI IT } \\
\text { Flexible exchange rate }\end{array}$ & 0.053 & 1.237 & 0.420 & 0.126 & 1.712 & 1.700 \\
\hline Managed exchange rate & 0.129 & 1.121 & 0.515 & 0.295 & 1.808 & 1.921 \\
\hline Taylor rule domestic inflatic & & & & & & \\
\hline $\mathrm{i}_{\mathrm{t}}=1.5 \Pi_{\mathrm{t}}^{\mathrm{h}}+0.5 \mathrm{y}_{\mathrm{t}}$ & 0.145 & 1.295 & 0.392 & 0.016 & 1.726 & 1.678 \\
\hline $\begin{array}{l}\text { Taylor rule CPI inflation } \\
\mathrm{i}_{\mathrm{t}}=1.5 \Pi_{\mathrm{t}}+0.5 \mathrm{y}_{\mathrm{t}}\end{array}$ & 0.054 & 1.234 & 0.419 & 0.126 & 1.709 & 1.704 \\
\hline
\end{tabular}

Taylor rule CPI vs Taylor rule domestic inflation targeting: The domestic and the CPI inflation can be compared in terms of the taylor rule .This is another characteristic added in this study besides the other regimes. With this rule, the interest rate is adjusted in response to the output and the inflation. The rule was supported by the theoretical models of Svensson (1997) and Ball (1997).In their models, the optimal policies are a version of the inflation targets and the Taylor rules. It is observed from the table 8 that with the domestic interest rate shock $\varepsilon_{t} \epsilon^{\epsilon}$, all the endogenous variables are constant or non stationary, not displaying correlations and auto-correlations. Unlike the CPI (IT), it is discovered as Svensson (2000) that the taylor rule excludes any direct important response to foreign shocks of the variables.. The volatility of the real exchange rate $\left(\mathrm{q}_{t}\right)$ with all the shocks is higher in the domestic than the CPI inflation instrument .Contrary to the domestic inflation $\left(\pi^{\mathrm{h}}\right)$ and the output $(\mathrm{y})$ which are higher in the CPI inflation, nearly with all the shocks. The domestic interest rate (i )is higher with the domestic inflation expect with the foreign inflation shock. The Figurer 37 to 41 illustrate the impulse response function of these variables face to different shocks in the case of taylor rule. In this context the blue line designs the domestic taylor rule while the black line displays the CPI taylor rule. Finally, the welfare loss in the Table 2 exhibits that the CPI inflation taylor rule is slightly higher than the domestic inflation taylor rule, with almost all the shocks except the productivity. This finding differs from the one revealed by Gali \&Monacelli (2005) whose welfare loss is higher with the domestic inflation compared to the CPI instrument taylor rule.

Table8: Unconditional standard deviation for domestic interest rate shock(epsei= $\left.\varepsilon_{t}{ }^{\epsilon}\right)$

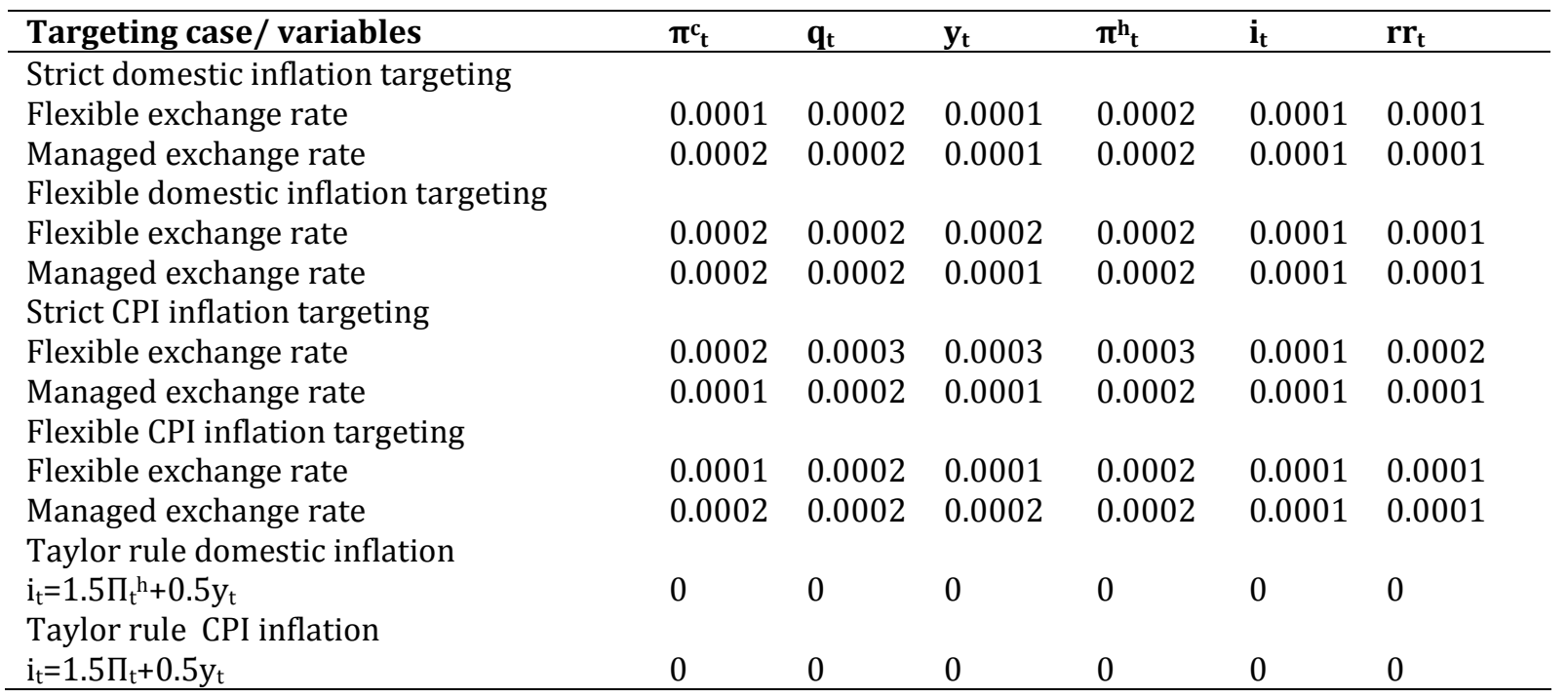




\section{Conclusion}

Although the (IT) is not yet applied in Tunisia. The specificity of this study is comparing different monetary policies and exchange rate regimes in terms of volatility and welfare to choose the optimal case in a small open economy like Tunisia. In this paper a DSGE model is employed in Tunisian economy with some features to capture the persistence and the covariance in the data like the habit formation and the investment adjustment cost. The most striking result, is that the social loss is higher with the managed exchange rate than the flexible exchange rate regime for almost all the shocks. Also regarding the( IT)index, it is revealed that in contrast to Parrado (2004), the CPI outperforms the domestic inflation. Finally, it is discovered that the strict is superior to the flexible (IT) with the major of the shocks. A future research can be worthwhile in comparing targeting the headline or the core CPI inflation or targeting sectoral inflation i.e., subsidized or non subsidized good vs the CPI inflation like the study of Ben Aissa \& Rebai (2012). The model's parameters are conform to the Tunisian economy. Our contribution can be seen in capturing some features in the model like for example the nominal rigidity in the imported sector in the Tunisian economy. This is because the imported goods sector uses labor forces. Also the remittance is added in the model because their significant impact on the real exchange rate through the uncovered interest parity condition ,as well as their effect on the output. Also comparing these different regimes in terms of $\mathrm{t}$ welfare and adding the forward component in the monetary rule can enrich this study.

\section{References}

Palma, A, A. \& Portugal, M. S. (2014). Preferences of the Central Bank of Brazil under the inflation targeting regime: Estimation using a DSGE model for a small open economy. Journal of Policy Modeling, 36, 824-839.

Ashot, M. E., Norris, D. \& Stepanyan, A. (2009). A New Keynesian Model of the Armenian Economy. IMF Working Paper No.WP/09/66.

Ball, L. (1999). Policy Rules for Open Economies. University of Chicago Press. National Bureau of Economic Research.

Ball, L. (1997). Efficient rules for monetary stability. Working paper no. 5952. NBER, Cambridge, MA.

Ben-Hadj-Boubaker, H. (2011). Inflation Forecast-Based Rule for Inflation Targeting: Case of Some Selected MENA Countries. Politics and economic development. The 17th Annual Conference of the ERF. Renaissance Antalya Beach Resort \&Spa Turkey.

Ben-Aissa, M. \& Rebei, N. (2012).Price Subsidies and the Conduct of Monetary Policy. Journal of macroeconomics, 34,769-787.

Chockri, A. \& Frihka, I. (2011). La portée de la politique de ciblage d'inflation: Approche analytique et empirique pour le cas Tunisien. Panoeconomicus, 1, 91-111.

Chow, H. K., Lim, G. C. \& McNelis, P. D. (2014). Monetary regime choice in Singapore: Would a Taylor rule outperform exchange-rate management? Journal of Asian Economics, 30, 63-81.

Gali, J. \& Monacelli, T. (2005). Monetary policy and exchange rate volatility in a small open economy .Review of Economic Studies, 72, 707-734.

Hammond, G. (2012). State of the art of inflation targeting . Centre for Central Banking Studies, Handbook No. 29. Centre for Central Banking Studies. Bank of England .

Huseynov, S. (2010). An estimated DSGE model for Turkey with a monetary regime change. Central European university. Department of Economics. CEU etD collection.

Ireland, P. (2004).Money's role in the monetary business cycle. Journal of Money. Credit, and Banking, 36(6),969-983.

Jouini, N. \& Rebei, N. (2014). The Welfare Implications of Services Liberalization in a Developing Country: Evidence from Tunisia. Journal of Development Economics, 106, 1-14.

Justiniano, A. \& Preston, B. (2010a). Monetary Policy and Uncertainty in an Empirical Small Open Economy Model. Journal of Applied Econometrics, 25(1).

Juillard, M., Phillipe, K., Douglas, L. \& Paolo, P. (2006).Welfare-based monetary policy rules in an estimated DSGE model of the US economy. Working paper series $\mathrm{N}^{\circ}$ 0613.European Central Bank.

Leitemo, K. ( 1999). Inflation Targeting Strategies in Small Open Economies. Memorandum, Department of Economics, University of Oslo, No. 1999,21

Parrado, E. (2004). Inflation Targeting and Exchange Rate Rules in an Open Economy . Central Banking, Analysis, and Economic Policies Book Series. IMF Working Paper No. 04/21 .

Peiris, J. \& Saxegaard, M. (2007). An Estimated DSGE Model for Monetary Policy Analysis in Low-Income Countries. African Department. IMF Working Paper No.07/282. 
Rudebusch, D. \& Svensson, L. E. O. (1998). Policy Rules for Inflation Targeting. NBER Working Paper No. 6512

Svensson, L. E. O. (1997b). Inflation Targeting in an Open Economy: Strict vs. Inflation Targeting.? Public Lecture at Victoria University of Wellington, Reserve Bank of New Zealand Discussion Paper, forthcoming.

Svensson, L. E. O. (2000).Open-economy inflation targeting. Journal of International Economics, 50, 155183.

\section{Annex 1}

\section{Regime III: CPI vs domestic inflation Targeting: Flexible exchange rate}

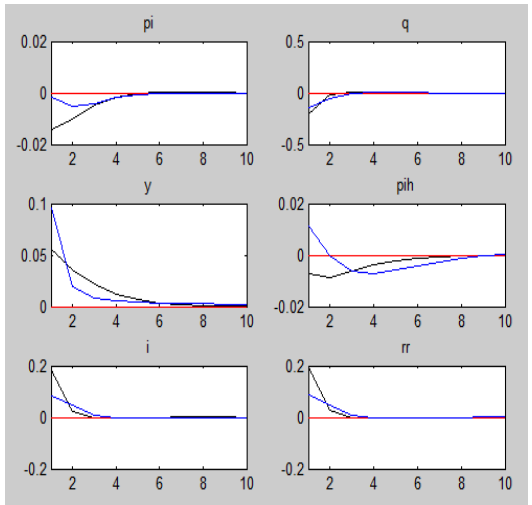

Fig. 13: orthogonalized shock to $\varepsilon_{\mathrm{t}} \mathrm{y}^{*}$

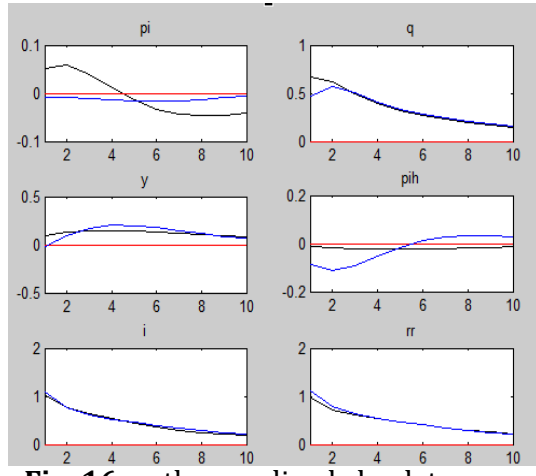

Fig. 16: orthogonalized shock to $\varepsilon$ i $^{*}$
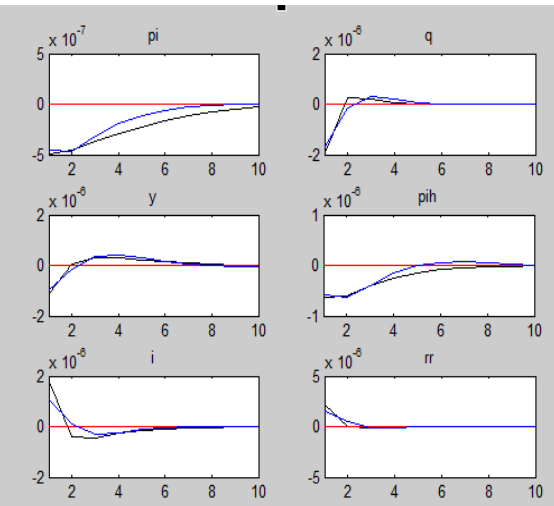

Fig. 14: orthogonalized shock to $\varepsilon t^{\epsilon}$

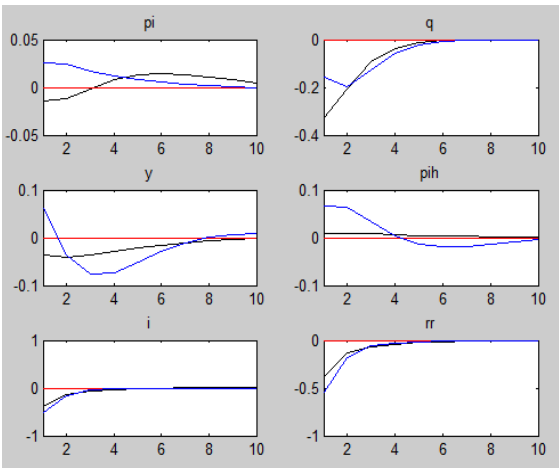

Fig. 17: orthogonalized shock to $\varepsilon \pi^{*}$

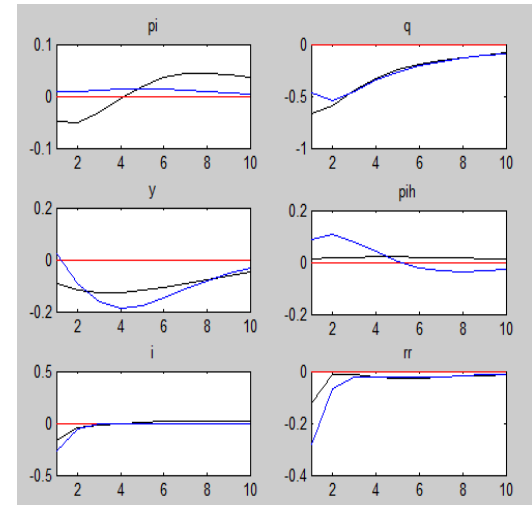

Fig. 15: orthogonalized shock to $\varepsilon \zeta_{t}$

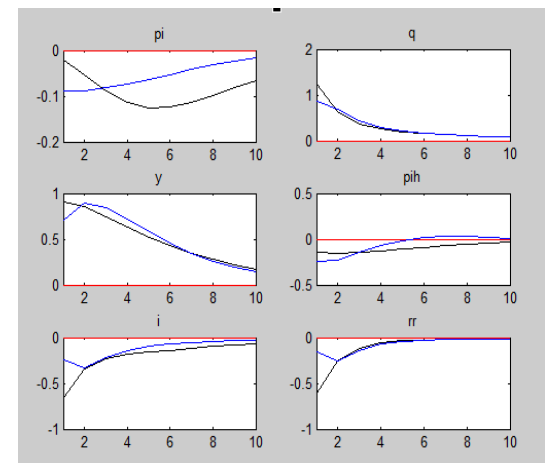

Fig. 18: orthogonalized shock to $\varepsilon^{\mathrm{z}}$

Regime IV: CPI vs domestic IT: Managed exchange rate.

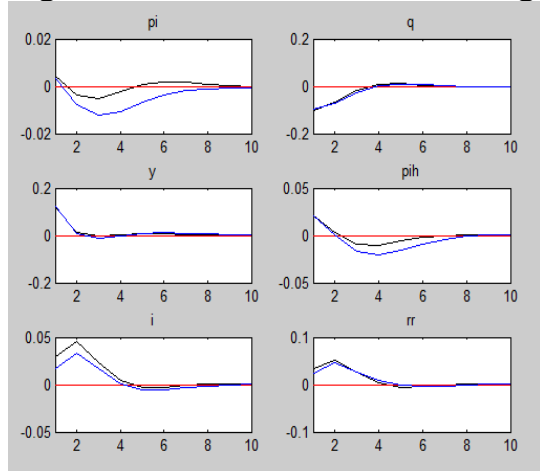

Fig. 19: orthogonalized shock to $\varepsilon_{\mathrm{t}} \mathrm{y}^{*}$

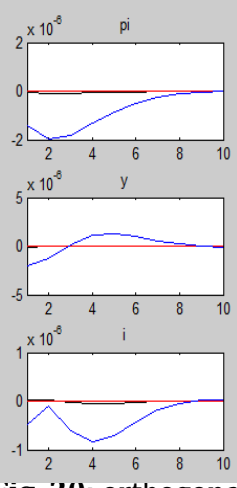

Fig. 20: orthogonalized shock to $\varepsilon_{\mathrm{t}}^{\epsilon}$
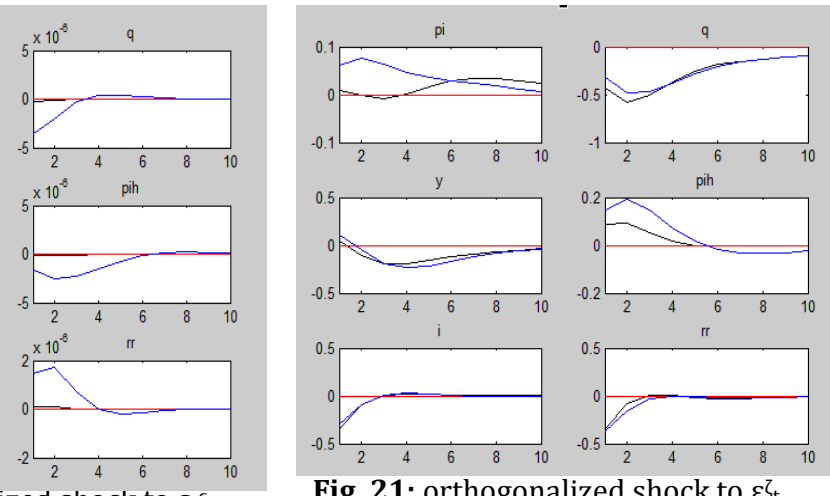

Fig. 21: orthogonalized shock to $\varepsilon \zeta_{t}$ 


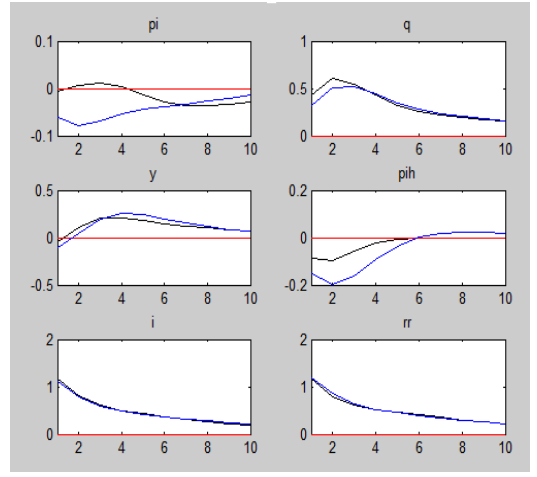

Fig. 22: orthogonalized shock to $\varepsilon_{\mathrm{i}^{*}}$

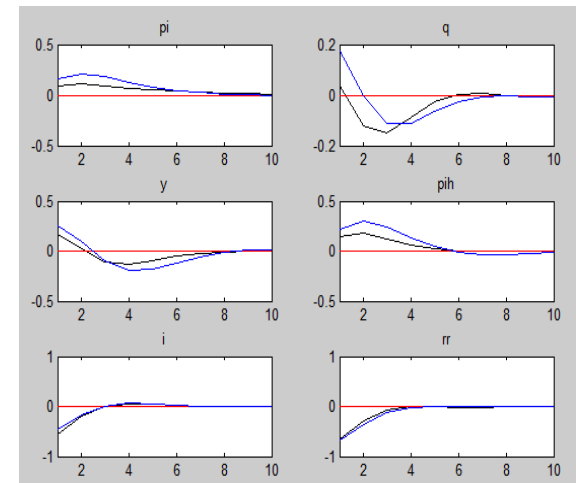

Fig. 23: orthogonalized shock to $\varepsilon^{\frac{6}{4}}$

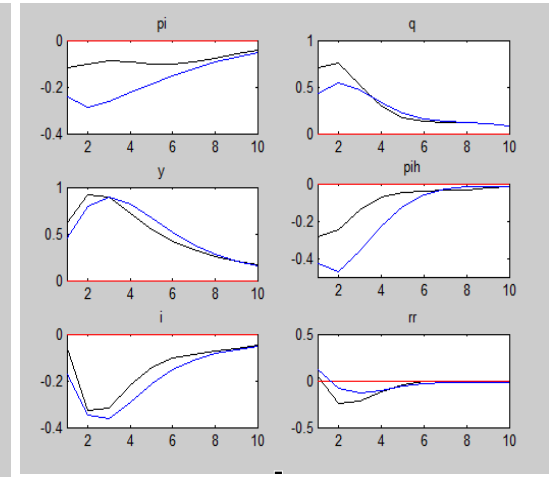

Fig. 24: orthogonaized shock to $\varepsilon^{\mathrm{z}}$

Regime V:Flexible vs strict CPI inflation targeting: Flexible exchange rate.

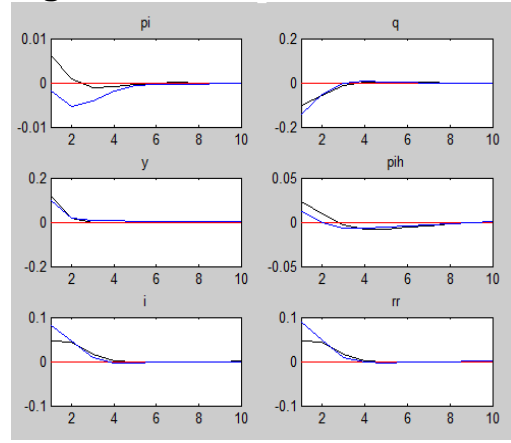

Fig. 25: orthogonalized shock to $\varepsilon_{\mathrm{t}} \mathrm{y}^{*}$

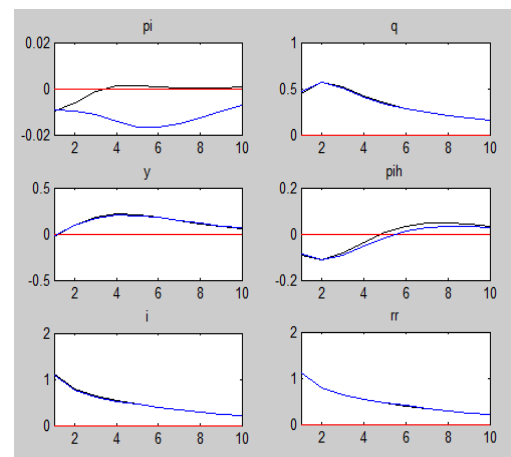

Fig. 28: orthogonalized shock to $\varepsilon \mathrm{i}^{*}$
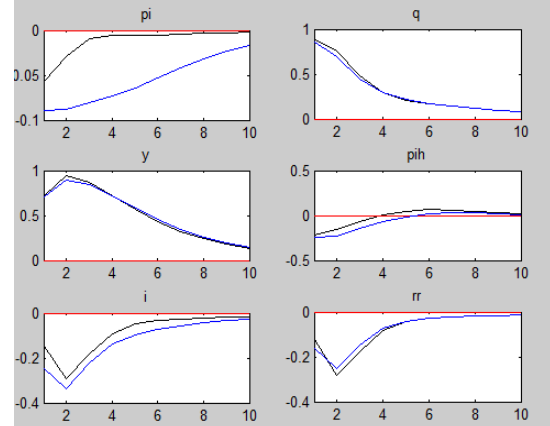

Fig. 26: orthogonalized shock to $\varepsilon_{\mathrm{t}^{\mathrm{Z}}}$

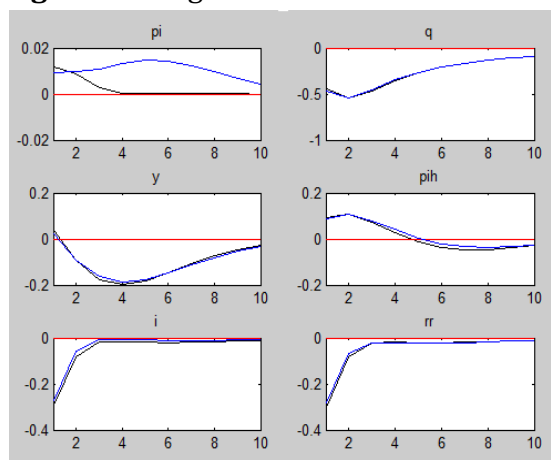

Fig. 29: orthogonalized shock to $\varepsilon \zeta_{t}$
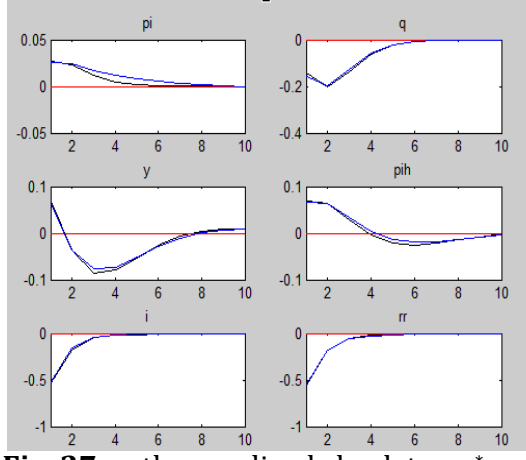

Fig. 27: orthogonalized shock to $\varepsilon \pi^{*}$

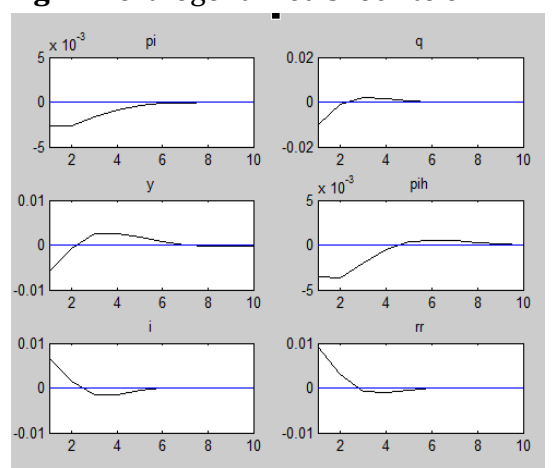

Fig. 30: orthogonalized shock to $\varepsilon_{\mathrm{t}}^{\epsilon}$

\section{Regime VI: Flexible vs strict domestic inflation targeting: Flexible exchange rate}

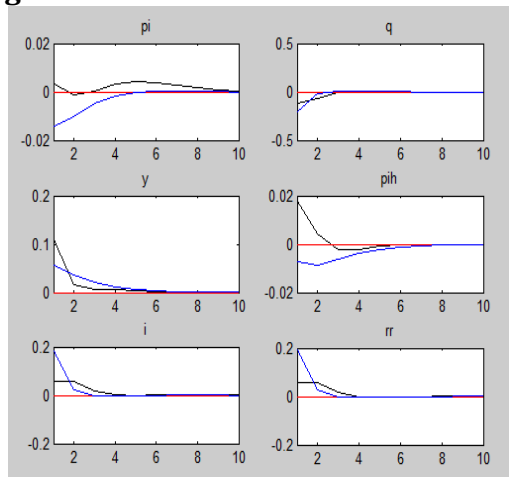

Fig. 31: orthogonalized shock to $\varepsilon_{\mathrm{t}}^{\mathrm{y}}$

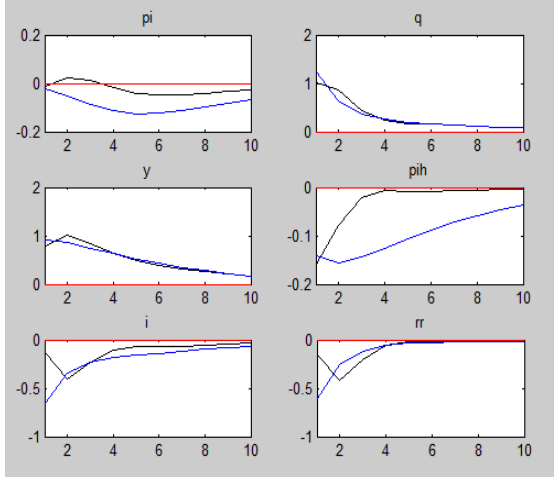

Fig. 32: orthogonalized shock to $\varepsilon^{\mathrm{z}}$

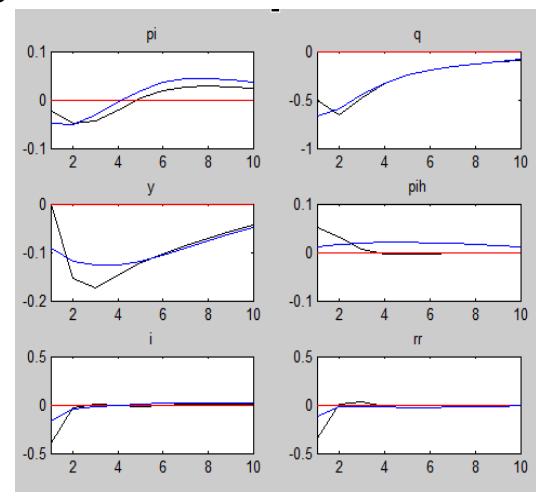

Fig. 33: orthogonalized shock to $\varepsilon\}_{t}$ 


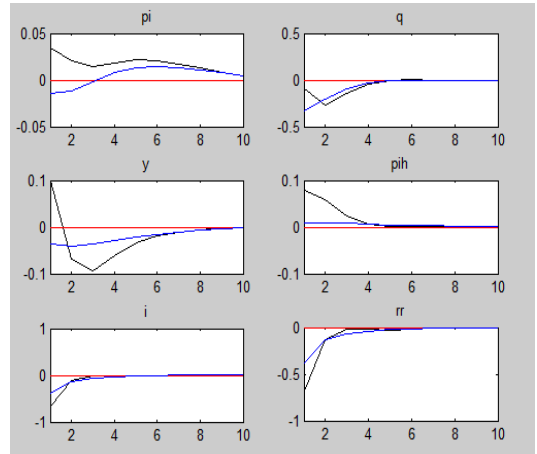

Fig. 34: orthogonalized shock toe $\pi^{*}$

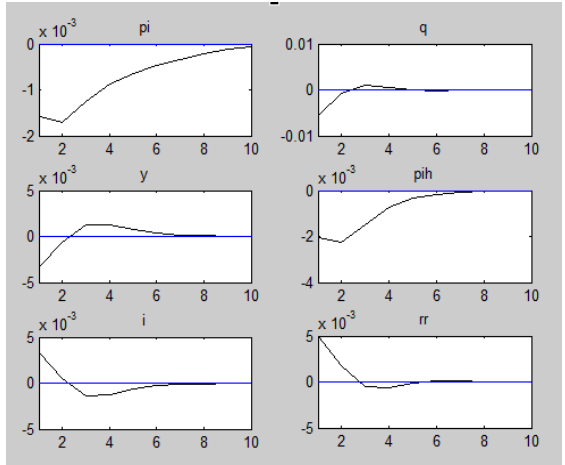

Fig. 3 : orthogonalized shock to $\varepsilon_{\mathrm{t}^{\epsilon}}$

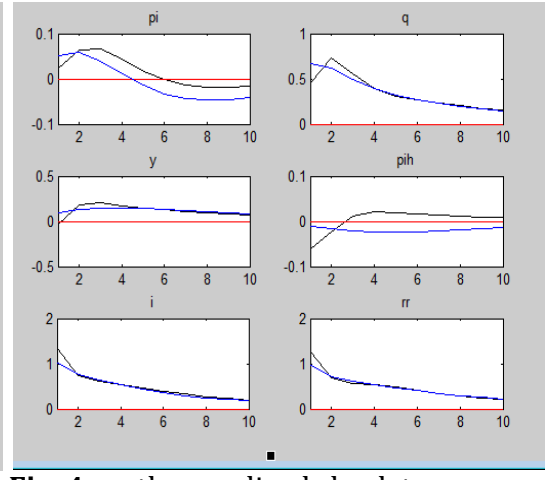

Fig. 4 : orthogonalized shock to $\varepsilon_{\mathrm{i}^{*}}$

\section{Regime VII: Taylor rule domestic vs CPI inflation}

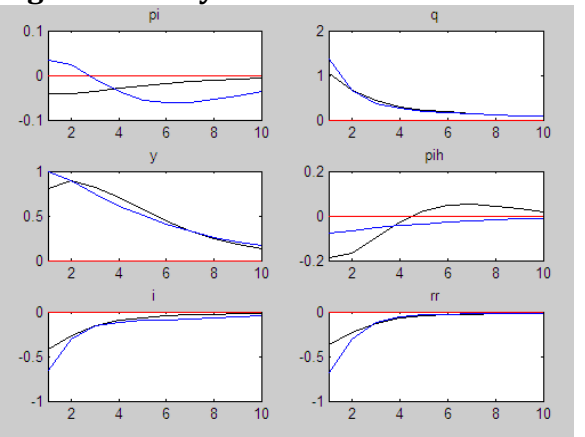

Fig. 35: orthogonalized shock to $\varepsilon^{\mathrm{z}}$
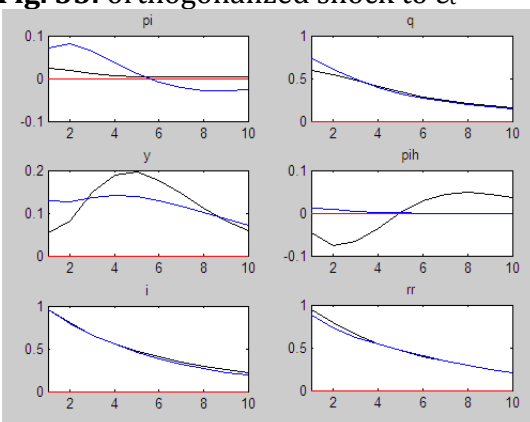

Fig. 40: orhtogonalized shock to $\varepsilon_{\mathrm{i}^{*}}$

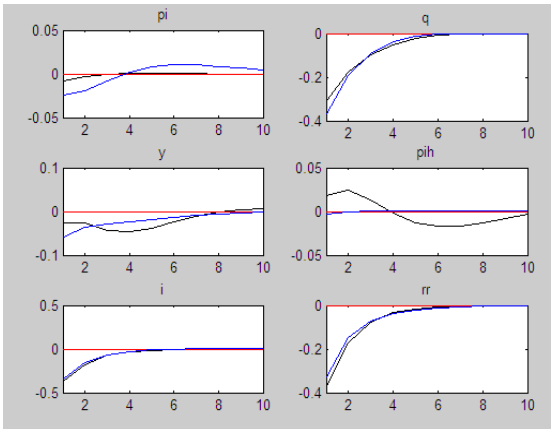

Fig. 38: orthogonalized shock to $\varepsilon \pi^{*}$

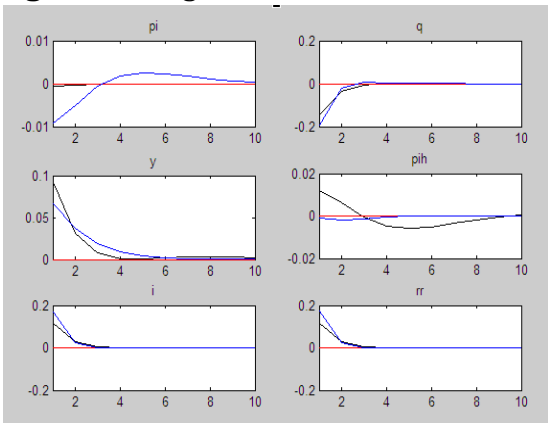

Fig. 41: orthogonalized shock to $\varepsilon_{\mathrm{t}} \mathrm{y}^{*}$

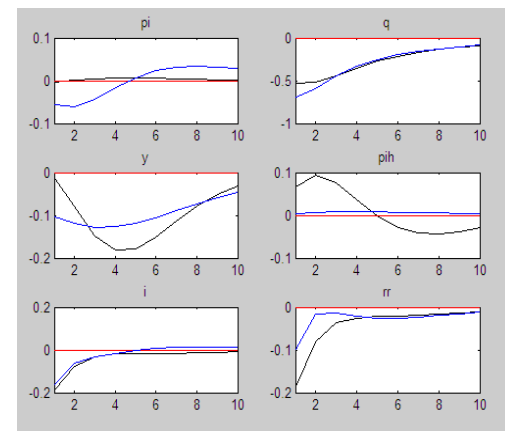

Fig. 39: orthogonálized shock to $\varepsilon s_{t}$

Acknowledgment: We are grateful to Johannes Pfeifer, Sébastien Villemot, Ferhat Mihoubi, LarsSvensson, Stephane Adjemian for their support and useful remarks. 